\title{
DEFICYT OBYWATELSTWA
}

Jubileusze ważnych wydarzeń politycznych sprzyjają pisaniu tekstów pochwalnych. Osiagnięcia polskiej transformacji sa powszechnie znane, choć niekoniecznie powszechnie doceniane. Chciałbym w tym miejscu spojrzeć na rozpoczętą przed ćwierćwieczem reformę samorządową bardziej krytycznie. Także dlatego, że jesteśmy właśnie świadkami ujawnienia się wyraźnego rozmijania się społecznych nastrojów z dobrym z reguły samopoczuciem polityków, czego wynikiem jest obecne polityczne trzęsienie ziemi. Zapowiedzia kontestacji istniejącej formy lokalnej demokracji była po wyborach samorzadowych 2010 r. krytyka dotychczasowej ordynacji wyborczej. Jej większościowy charakter uniemożliwiał wprowadzenie choćby jednego radnego do Rady Miasta Poznania spośród kandydatów My-Poznaniacy, ruchu społecznego, który uzyskał wtedy blisko 10-procentowe poparcie. Krytyka tej ordynacji nasiliła się przed wyborami 2014 r. Dodać należy, że narodziny na początku tej dekady i względny sukces ruchów miejskich w ostatnich wyborach, a także liczne przypadki wprowadzania tzw. budżetu obywatelskiego wskazują na potrzebę pogłębienia demokracji lokalnej.

\section{JERZEGO REGULSKIEGO OCENA REFORMY PO PIĘTNASTU LATACH}

Punktem wyjścia jest dla mnie opublikowana w 2005 r. książka Jerzego Regulskiego Samorzqdna Polska, wydana w serii pod znaczacym tytułem Szklane Domy. Jej autora nie trzeba przedstawiać. Był czołową postacia waskiej grupy inicjatorów i twórców tej reformy, pozostanie w naszej pamięci jej ikona. Jego napisana piętnaście lat po reformie samorządowej z 1990 r. książka ma szczególny walor. Jest chyba jedyną zwarta publikacja, w której prostym, zrozumiałym językiem przedstawiona została aksjologia reformy samorządowej, fundamentalne wartości i naczelne zasady tej reformy. W naszym publicznym dyskursie nie brakuje napisanych przez wybitnych autorów prac o filozofii odradzającej się polskiej demokracji. Wymienić tu można m.in., w kolejności alfabetycznej, prace Leszka Balcerowicza, Aleksandra Halla, Jarosława Gowina, Zdzisława Krasnodębskiego, Marcina Króla, Jacka Kuronia, Janusza 
Lewandowskiego, Adama Michnika, Wiktora Osiatyńskiego, Marka Safjana, Jana Sowy, Jadwigi Staniszkis, Jerzego Szackiego, Pawła Śpiewaka czy Józefa Tischnera. W debacie o naczelnych wartościach polskiej demokracji wypowiadają się regularnie uczeni, publicyści, politycy, duchowni. Przedmiotem ich uwagi jest wolność słowa, tradycja, relacje państwo-kościół, miejsce Polski w Unii Europejskiej, model gospodarki, system partyjny czy rodzaj ordynacji wyborczej. Główna linia podziału przebiega między liberałami a konserwatystami, ale oba te nurty są bardzo zróżnicowane, a w tej debacie biorą także udział autorzy spoza centrum, zarówno z lewicy socjalnej, jak i narodowcy.

Takiej narracji brakuje w przypadku reformy samorządowej. Bogata literatura na ten temat ma na ogół charakter profesjonalny. Pisana jest przez prawników, ekonomistów, geografów czy socjologów dla waskiego grona badaczy lub dla nieco szerszego kręgu urzędników. Prace te są często bardzo wartościowe z naukowego czy praktycznego punktu widzenia, ale przeznaczone są dla czytelników-profesjonalistów, a nie dla czytelników-obywateli. Nie funkcjonują w szerszym obiegu, nie wywołują dyskusji. Sam ten fakt jest znaczący. Pokazuje bowiem, że samorząd jest traktowany głównie jako narzędzie sprawowania władzy na niższych szczeblach, a jedyne problemy, jakie w związku z jego działaniem się pojawiaja, mają charakter techniczny. Jak mawiał pierwszy prezydent odrodzonego samorzadu Poznania - Wojciech Szczęsny Kaczmarek - „rura jest apolityczna”. Ta metafora jest jednak tylko częściowo słuszna. Rura sama w sobie oczywiście jest „apolityczna”. Jednak to, komu przede wszystkim będzie służyła, czy w pierwszej kolejności mieszkańcom grodzonego osiedla, czy też betonowego blokowiska, jest kwestią politycznego wyboru. W tym sensie jeszcze bardziej polityczny charakter niż rura mają takie elementy gminnej infrastruktury, jak drogi, ścieżki rowerowe, parkingi czy autobusy. Polityczny charakter ma wreszcie decyzja, jakie wydatki budowa owej rury wyprze z budżetu gminy, czy zostanie ona położona kosztem dofinansowania promującego gminę widowiska sportowego czy raczej kosztem obiadów w lokalnej szkole dla dzieci z niezamożnych rodzin. Zaspokajanie potrzeb mieszkańców to kluczowe zadanie samorządu. Ale nie może on wyłącznie ograniczać się do tej roli. Samorząd ma nie tylko - by użyć kolejnej zakorzenionej w polskim dyskursie publicznym metafory - dostarczać ciepłą wodę w kranie, lecz także współtworzyć społeczeństwo obywatelskie. Jak twierdzą wybitni brytyjscy badacze samorządu - John Stewart i Michael Clarke - mieszkańcy są nie tylko klientami lokalnej władzy, ale także obywatelami gminy, a władze lokalna ma obowiązek zarówno „zarządzania zorientowanego na mieszkańca-klienta”, jak i „zarządzania zorientowanego na mieszkańca-obywatela"1.

Powróćmy do książki Regulskiego. Samorząd w jego ujęciu miał być ważnym elementem ustrojowym państwa obywatelskiego, będącego kompromisem między państwem opiekuńczym a państwem wolnorynkowym, państwa kierującego się zasadą pomocniczości, państwa zdecentralizowanego, zorga-

${ }^{1}$ J. Stewart, M. Clarke The Public Orientation and the Citizen, Local Government Public Board, Luton 1987, 
nizowanego terytorialnie, opartego na organizacjach społeczności lokalnych, państwa wielopodmiotowego.

Z tej perspektywy sam Regulski dokonał oceny reformy samorządowej po 15 latach. Obok niewątpliwych sukcesów, takich jak rozbicie monopolu władzy centralnej, stworzenie nowych instytucji, przebudowa sektora usług publicznych i wielu innych, dostrzegł sporo niepowodzeń. Wiąał je z reguły z naciskiem rozmaitych wpływowych grup interesu, które albo blokowały niezbędne ze społecznego punktu widzenia zmiany w regulacjach prawnych, albo, co gorsza, forsowały skutecznie zmiany korzystne jedynie z ich partykularnego punktu widzenia. Z tych powodów klub PZPR zablokował w Sejmie w 1989 r. wprowadzenie obowiązkowego zrzeszania się miast i gmin, gdyż umocniłoby to zdecydowanie głos władz lokalnych ${ }^{2}$. To jednak niejedyny problem polskiej samorządności. Jak stwierdził Regulski w 2005 r.: „samorząd znalazł się na zakręcie. Od tego, jak on zostanie pokonany, w dużej mierze zależy rozwój kraju”3. Głównym problemem, który sprzyja dysfunkcjonalności samorządów, jest dla niego niedorozwój społeczeństwa obywatelskiego, gdyż „uwaga skoncentrowana jest jedynie na aspektach prawnych czy gospodarczych przebudowy państwa, pozostawiajac sferę funkcjonowania społeczeństwa na uboczu"4. Tworzenie się społeczeństwa obywatelskiego jest jego zdaniem procesem, który polityka państwa powinna stymulować: „w Polsce ramy prawne i instytucjonalne samorządu zostały stworzone, natomiast powszechnie stwierdza się, że rozwój społeczeństwa obywatelskiego jest opóźniony i wymaga radykalnego przyśpieszenia"s.

Zdaniem autora niedorozwój społeczeństwa obywatelskiego sprzyja szeregowi niekorzystnych zjawisk, takich jak upartyjnienie administracji, wzajemna nieufność samorządów i organizacji obywatelskich, utożsamianie przez obywateli samorządów z państwem. Inne negatywne aspekty polskiej samorządności - zdaniem Regulskiego - to przekazywanie przez rząd gminom nowych zadań bez środków na ich realizację, niedostateczne rozdzielenie kompetencji władz państwowych i wojewódzkich, uczynienie z wojewodów reprezentantów lokalnych elit partii rządzącej zamiast reprezentantów państwa, utworzenie powiatów grodzkich w małych miastach, „ustanowienie ustroju powiatu jako analogicznego do gminy"6. Last, but not least, zakusy recentralizacyjne, czego wyrazem było - według autora - wyłaczenie w 1998 r. z reformy powiatów inspekcji sanitarnej, weterynaryjnej i policji.

Szczególnie krytycznie oceniał Regulski prawo regulujące relacje między wójtem (burmistrzem, prezydentem) i radą gminy. Według oryginalnego projektu reformy samorządowej w 1990 r. wójt miał przewodzić radzie, być liderem politycznym, a urzędem miał kierować menadżer, sekretarz gminy. Niestety, przeforsowano poprawkę do tego projektu, która uczyniła wójta kierownikiem urzędu i stworzyła funkcję przewodniczącego rady. Rezultatem tej

\footnotetext{
2 J. Regulski, Samorzadna Polska, Rosner i Wspólnicy, Warszawa 2005.

3 Ibidem, s. 77.

4 Ibidem, s. 99.

5 Ibidem, s. 94.

6 Ibidem, s. 98.
} 
poprawki było wspomniane wyżej upartyjnienie administracji samorządowej oraz powstanie strukturalnego konfliktu o władzę i prestiż między wójtami a przewodniczącymi rady. Konflikty te często paraliżowały pracę samorządów. Nie zawsze były konfliktami merytorycznymi, bardzo często przede wszystkim konfliktami ambicjonalnymi. W powstałej sytuacji za pragmatyczne rozwiązanie uznano stopniowe ograniczenie roli przewodniczących. Decydujące znaczenie miała tu ustawa z 2002 r. o bezpośrednich wyborach wójtów, burmistrzów i prezydentów.

Profesor Regulski już w trzy lata po tej ogromnie znaczącej zmianie ustroju samorządowego pisał:

\begin{abstract}
Wzmacniając władzę wykonawczą w gminie, uczyniono z wójtów i burmistrzów osoby wyposażone w pełnię władzy, ale wyłączone spod jakiejkolwiek kontroli. Wójt może - w oparciu o własne poglądy - dysponować mieniem, zatrudniać ludzi w administracji według własnego uznania, podejmować decyzje administracyjne, nawet te ograniczające prawa obywatelskie. Może całkowicie ignorować radę, której uchwały - nawet te odmawiające mu absolutorium nie mają znaczenia. Wójt jest praktycznie nieodwoływalny, gdyż można tego dokonać jedynie w wyniku referendum, które wobec ustawowego progu rzadko osiaganej frekwencji na ogół jest nieważne. W rezultacie mamy sytuację, gdy prezydent miasta aresztowany jako podejrzany o malwersację i korupcję rządzi miastem z więzienia, a po warunkowym zwolnieniu nadal zarządza majątkiem publicznym. A przecież jako oskarżony o nadużycia nie mógłby być zatrudniony nawet jako magazynier?
\end{abstract}

Ten patologiczny mechanizm zdaniem Regulskiego wymaga zmian, niszczy bowiem istotę samorządności, choćby przez ubezwłasnowolnienie rady. Autor proponuje umocnienie pozycji rady przez: „jasne zdefiniowanie zadań, praw i odpowiedzialności rad i radnych [...] rada jest bezradna, nie dysponuje żadnymi środkami, aby wójta zmusić do respektowania jej ustaleń” oraz „dokonanie wyraźnego rozdziału stanowisk politycznych i administracyjnych", gdyż wybierać można liderów politycznych, a nie zarządzających menadżerów, a tymczasem taki paradoks tworzy właśnie wspomniana ustawa z 2002 r. Postulował także zmianę ordynacji wyborczej na taka, która umocni rolę lokalnych społeczności kosztem partii politycznych przez wybory „rady o charakterze reprezentacji wybierane w okręgach małomandatowych. Siła partii będzie zależna od wyników wyborów w okręgach, a nie odwrotnie"10.

Książka Samorzadna Polska nie podejmuje problemu tzw. jednostek pomocniczych, samorządów najniższego szczebla powstałych po zlikwidowaniu w dużych miastach (poza Warszawa) dzielnic administracyjnych. Problem ten zaprzątał jednak uwagę Regulskiego, o czym świadczy przygotowany w 2008 r. pod jego kierunkiem projekt reformy jednostek pomocniczych Poznania. Zdaniem ekspertów powstałe po likwidacji w 1990 r. dzielnic rady osiedli nie służyły upodmiotowieniu mieszkańców, decentralizacji władzy, praktycznej obywatelskiej edukacji. Nowy projekt zespołu Jerzego Regulskiego pilotowany w Poznaniu przez specjalnego pełnomocnika prezydenta Ry-

\footnotetext{
7 Ibidem, s. 116-117.

8 Ibidem, s. 122.

9 Ibidem, s. 188.

${ }^{10}$ Ibidem, s. 122.
} 
szarda Grobelnego - Włodzimierza Urbańczaka - postulował daleko idące zmiany w ich funkcjonowaniu. Zamiast istniejących wówczas 68 osiedli miało powstać 16 dzielnic, z których każda miała liczyć sobie około 30 tys. mieszkańców. Każda rada miała wyłonić z siebie trzyosobowy zarząd, w skład którego mogliby wchodzić także fachowcy spoza jej grona. Na terenie każdej z nich miał powstać „punkt obsługi mieszkańców” z kilkoma pracownikami urzędu oddelegowanymi z Urzędu Miasta, jednostką straży miejskiej oraz publicznym dostępem do Internetu. Postulowano istotne zwiększenie kompetencji rad osiedli. Obok reprezentowania mieszkańców miały one także odpowiadać za „bieżące utrzymanie oświaty gminnej” i remonty jej placówek. Każda rada miała dysponować rocznym budżetem. Sredni budżet dla takiej dzielnicy miał wynosić około $18 \mathrm{mln}$ zł, w tym $14 \mathrm{mln}$ na oświatę. Projekt przewidywał możliwość przekazania w zarząd radzie osiedla części mienia komunalnego. Nowe nazwy tak wyłonionych 16 nowych dzielnic miały wybrać same rady ${ }^{11}$.

Miałem okazję sprawdzić, jak propozycja ta została przyjęta przez poznaniaków. W zleconym mi badaniu uczestniczyły trzy grupy: działacze rad osiedli, dyrektorzy szkół oraz „zwyczajni” mieszkańcy ${ }^{12}$. Wyniki okazały się niezwykle pouczajace. Potwierdzały starą prawdę, że „punkt widzenia, zależy od miejsca siedzenia”. Działacze osiedlowi projekt w zasadzie odrzucali. Co zrozumiałe, nie podobało im się zwłaszcza ograniczenie liczby rad z 68 do 16 . Mówili, że grozi to „zniknięciem spraw małych osiedli, w szerszych strukturach”, obawiali się ,zniszczenia powstałych więzi społecznych”, ,zaniku oddolnych inicjatyw", połączenia w jedną dzielnicę osiedli domów jednorodzinnych i bloków, dodatkowych kosztów. Niektórzy z radnych osiedlowych dopuszczali powstanie 16 dzielnic, ale jedynie przy zachowaniu dotychczasowych osiedli, czyli proponowali system dwuszczeblowy. Dyrektorzy szkół generalnie akceptowali zmiany, ale... nie chcieli, aby objęły one placówki oświatowe. Entuzjastycznie do projektu podeszli za to „zwyczajni” mieszkańcy. Co ciekawe, najbardziej podobał im się pomysł utworzenia w dzielnicach „punktów obsługi”. Jak stwierdzali, „urzędy w Poznaniu to matrix”, a powstanie takich punktów znacząco ułatwi im załatwianie wielu spraw. Nie da się ukryć, że pragmatyczny postulat „urząd bliżej mieszkańców” przekonywał ich bardziej niż obywatelska idea „więcej władzy w ręce mieszkańców”. Niektórzy postulowali, aby w tych dzielnicowych biurach obsługi można było nawet oddawać PIT-y. Okazało się bowiem, że mieszkańcy nadal myślą o mieście w kategoriach pięciu dzielnic administracyjnych, a urzędy skarbowe traktuja jako agendę dawnych urzędów dzielnicowych. W trakcie dyskusji mieszkańcy wskazywali także na to, że nowe dzielnice mogłyby stać się w przyszłości jednomandatowymi okręgami wyborczymi. W momencie ożywionej debaty o JOW-ach warto o tym przypomnieć. Dodać należy, że jeżeli gdziekolwiek ten typ ordynacji wyborczej ma sens, to właśnie na najniższym szczeblu, gdzie ludzie rzeczywiście moga się wzajemnie znać.

\footnotetext{
${ }^{11}$ Koncepcja reformy jednostek pomocniczych w Poznaniu. Projekt Fundacji Rozwoju Demokracji Lokalnej pod kierunkiem J. Regulskiego, 2008, Prezentacja dla radnych, oprac. W. Urbańczyk.

${ }^{12}$ K. Podemski, Opinia publiczna wobec proponowanej reformy jednostek samorzadowych miasta Poznania. Raport z jakościowych badań socjologicznych, Poznań 2008.
} 


\section{CZY KRYTYKA JERZEGO REGULSKIEGO SIĘ ZDEZAKTUALIZOWAŁA?}

Od krytycznej analizy głównego autora polskiej reformy samorządowej minęło 10 lat. Czy jego spostrzeżenia i obawy się potwierdziły?

Chciałbym skoncentrować się tu na dwóch istotnych problemach: skutkach ordynacji wyborczej wójtów, burmistrzów i prezydentów oraz na funkcjonowaniu jednostek pomocniczych w miejsce dotychczasowych dzielnic.

\section{Konsekwencje nowej ordynacji wyborczej w wyborach wójtów, burmistrzów i prezydentów}

Przekonanie o szkodliwości konfliktu między władzą wykonawczą a przewodniczącym rady krytykowane także przez Jerzego Regulskiego oraz naciski silnego lobby prezydentów, burmistrzów i wójtów zaowocowały zmiana reguł samorządowej polityki przez wprowadzenie w 2002 r. zasady bezpośredniego wyboru władzy wykonawczej przez mieszkańców.

Ordynacja wyborcza z 2002 r. wyraźnie sprzyja ciagłości władzy wykonawczej. Potwierdzają to statystyki. Według danych przygotowanych przez Fundację Rozwoju Demokracji Lokalnej w wyborach samorządowych w 2010 r. ponownie wybrano około 70\% wójtów, burmistrzów i prezydentów łącznie, w tym samych prezydentów ponownie wybrano aż w $76 \%$ przypadków. Dla porównania, znacznie mniej, gdyż tylko $40 \%$ radnych zostało wybranych po raz kolej$n y^{13}$. W 2014 r. w dyskursie publicznym wyraźnie pojawiła się krytyka fenomenu wiecznych prezydentów, a na scenie politycznej pojawiły się liczne ruchy miejskie kontestujące nie tylko politykę dotychczasowych prezydentów miast, ale i sam fakt pełnienia przez nich funkcji przez kilka kadencji. Zaowocowało to zmianami władzy wykonawczej w wielu miastach i spadkiem odsetka prezydentów wybranych ponownie z $76 \%$ w ubiegłych wyborach do $61 \%$. Tym razem $32 \%$ kandydujących po raz kolejny prezydentów przegrało wybory. Jednocześnie spośród wybranych prezydentów w 2014 r. 63\% pełniło swój urząd co najmniej od dwóch kadencji. Ci, którzy pełnili tę funkcje po raz kolejny, wygrywali ponadto z reguły w I turze. Odwrotnie było w przypadku kandydatów, którzy po raz pierwszy objęli swoją funkcję. Stanowili oni przeszło $50 \%$ wójtów, burmistrzów i prezydentów wybranych w II turze, a jedynie $9 \%$ wybranych w turze $\mathrm{I}^{14}$. Jeżeli wziąć pod uwagę siedem największych (liczących sobie powyżej 400 tys. mieszkańców) polskich miast, to widać wyraźnie, że mamy do czynienia ze zjawiskiem wielokadencyjności raz wybranych władz. Najdłużej, gdyż piąta kadencję, od 1998 r. sprawuje władzę prezydent Gdańska Paweł Adamowicz (wygrał w I turze w 2006 i 2010, w II turze w 2014). Także od 1998 r. rządził Poznaniem Ryszard Grobelny, który w każdej z czterech kadencji zwyciężał

${ }^{13}$ Co nam powiedziaty wybory samorzadowe $w 2010$ roku w lat 20 od wprowadzenia reformy samorzadowej? Sukces? Porażka? Normalność? Raport z badań, Fundacja Rozwoju Demokracji Lokalnej, Małopolski Instytut Samorządu Terytorialnego i Administracji, Kraków 2010.

${ }^{14}$ C. Trutkowski, A. Kurniewicz, Bilans kadencji 2010-2014 w świetle wyników wyborów samorzadowych, Fundacja Rozwoju Demokracji Lokalnej [b.m. i b.r.]. 
dopiero w II turze, aż w 2014 r. przegrał wybory. Od 2002 r. czwartą kadencję rządzą Jacek Majchrowski, prezydent Krakowa (wygrywał tylko w II turze) oraz Rafał Dutkiewicz, prezydent Wrocławia (w I turze wygrał w 2006 i 2010, w II w 2002 i 2014). Od 2006 r. trzecią kadencję władzę sprawuje w Warszawie Hanna Gronkiewicz-Waltz (wygrała w I turze w 2010, a w II turze w 2006 i 2014), a w Szczecinie - Piotr Krzysztek (wygrywał tylko w II turze). Długo rządzą w swoich miastach także prezydenci miast mniejszej wielkości. Rekordzistą jest sprawujący funkcję szóstą kadencję (nieprzerwanie od 1993) Zygmunt Frankiewicz (Gliwice). Cztery kadencje (od 2002) rządzą także Tomasz Zaleski (Toruń), Tadeusz Ferenc (Rzeszów), Wojciech Szczurek (Gdynia) i Jacek Karnowski (Sopot).

Fakt sprawowania tak długo rządów przez prezydentów miast może budzić zdziwienie. O ile bowiem w małych społecznościach lokalnych zasoby elity profesjonalnej i politycznej są z natury szczupłe, o tyle przecież w miastach akademickich, posiadających liczną klasę polityczną i ekspertów powodem ciąłości władzy i braku konkurencji nie może być brak osób zdolnych do pełnienia tych funkcji. Należy sądzić, że poważna konkurencja nie pojawia się, gdyż wie, że z urzędującym prezydentem ma niewielkie szanse na zwycięstwo. Problem wielokadencyjności tkwi zatem w ordynacji wyborczej, którą nie ogranicza liczby kadencji.

Ze zjawiskiem wielokadencyjności wiąże się zatem kwestia bezalternatywności wyborów. Co ciekawe, w największym stopniu zjawisko to występuje w gminach miejskich, a spośród regionów - w Wielkopolsce. W świetle raportu Fundacji Rozwoju Demokracji Lokalnej:

\footnotetext{
W 2014 r. w 9,6\% gmin zgłoszono wyłącznie jednego kandydata na urząd wójta, burmistrza lub prezydenta. Był to spadek o 2,6\% w stosunku do roku 2010. Najliczniejszą kategorię gmin $\mathrm{z}$ wyborami bezalternatywnymi stanowiły gminy miejskie. Zjawisko to dotyczyło $17,2 \%$ jednostek tego typu 2 . W gminach wiejskich odsetek ten wyniósł $12,3 \%$, a w miejsko-wiejskich niecały $1 \%$. We wszystkich miastach na prawach powiatu wyborcy mogli głosować na więcej niż jednego kandydata.

W układzie regionalnym najwięcej gmin, w których głosowano na wyłącznie jednego kandydata, ponownie zanotowano w województwie wielkopolskim, chociaż na przestrzeni czterech lat nastapił spadek odsetka takich jednostek - z 19\% do 15\%. Szczególnie interesująco prezentuje się sytuacja w województwie podlaskim, w którym, w porównaniu z rokiem 2010, procent gmin z wyborami bezalternatywnymi zmalał w sposób zdecydowany (z 14\% do 1\%). Duże spadki odnotowały też województwa: dolnośląskie (z 9\% na 5\%) i lubuskie (z 15\% na 6\%). Zauważyć należy także, że w żadnym z pozostałych województw nie nastapił wyraźny wzrost skali omawianego zjawiska. W wyróżniających się pod tym względem województwach: śląskim oraz zachodnio-pomorskim wskaźnik ten zwiększył się o zaledwie $2 \%{ }^{15}$.
}

Dodać należy, że władza samorządowa, podobnie jak władza centralna, spoczywa w rękach mężczyzn w średnim wieku. W 2010 r. 80\% członków władz wykonawczych i 76\% radnych stanowili mężczyźni. Wśród wybranych radnych jedynie niespełna 3\% miało poniżej 25 lat ${ }^{16}$. Cztery lata później, mimo wprowadzenia obowiązku umieszczania na listach minimum 35\% kobiet, od-

15 Ibidem, s. 3.

${ }^{16}$ Co nam powiedziaty wybory samorzadowe $w 2010$ roku, op. cit. 
setek kobiet prezydentów wzrósł z 7\% do 11\%, a kobiet wójtów - z 9\% do 11\%. Co ciekawe, odsetek kobiet prezydentów był najwyższy w miastach powyżej 500 tys. mieszkańców (w tym w Warszawie i Łodzi) i wynosił 40\%, podczas gdy w miastach między 200 a 500 tys. mieszkańców kobiety stanowiły jedynie 6\% wybranych prezydentów ${ }^{17}$.

$$
* * *
$$

Władza wykonawcza uzyskała w 2002 r. w gminach silny mandat. Ograniczono nadmierny indywidualizm radnych (czasami warto byłoby posłużyć się tu kolokwialnym określeniem warcholstwo) i kierowanie się przez wielu radnych niesławną sarmacka zasadą liberum veto. Jednak trzy lata po wprowadzeniu nowej ordynacji wyborczej do władz wykonawczych samorządu krytycznie oceniał ją sam Jerzy Regulski. Miał rację, lekarstwo bowiem okazało się gorsze od choroby. Władza wykonawcza stała się w praktyce niemal niezależna od ciała przedstawicielskiego. Potwierdziły się jego obawy, że odwołanie prezydenta jest możliwe tylko teoretycznie, a rządy sprawować może on nie tylko mimo poważnych zarzutów (casus prezydenta Olsztyna), ale nawet z więzienia (casus prezydenta Gorzowa).

Nasz parlament stworzył władzom lokalnym komfort rządzenia, jakiego nie ma żadna inna władza w Polsce. Prezydent miasta ma w nim tak silna pozycję, jak prezydent państwa, a realną władzę taka, jak premier. Tymczasem w demokracji nie tylko decyzje władzy muszą być zgodne z prawem, ale i sama władza musi być ograniczona przez prawo. Władza prezydenta RP, raczej bardziej reprezentacyjna i symboliczna niż faktyczna, jest ograniczana przez możliwość pełnienia tej funkcji tylko przez dwie kadencji. Władzę premiera ogranicza Sejm, który może go w każdej chwili odwołać, gdy tylko zbierze odpowiednią większość poselskich głosów i znajdzie konkurenta. Podobne rozwiązania stosuje się w przypadku innych funkcji publicznych. Nawet władza rektora, który przecież ma nad sobą nie tylko senat uczelni, ale i ministerstwo, jest ograniczona ustawowo do dwóch kadencji. Jeżeli w większości krajów demokratycznych ogranicza się liczbę kadencji osób pełniących funkcje publiczne, nie ma powodów, aby ta słuszna zasada nie dotyczyła także wójtów, a zwłaszcza burmistrzów i prezydentów.

Tymczasem prezydent (a także burmistrz i wójt) mają w swojej gminie taka władzę, jaka miałby premier, gdyby był wybierany w bezpośrednich wyborach, a którego Sejm nie miałby prawa odwołać. W praktyce taki premier rządziłby pewno dopóty, dopóki by tylko zechciał. Dzięki nieograniczonej władzy stworzyłby sieć powiązań, która zapewniłaby mu lojalność elit politycznych, nawet tych pozornie „opozycyjnych”, gospodarczych, intelektualnych. Dzięki populistycznym obietnicom wygrywałby każde wybory. Jego twarz, ciagle obecna w mediach, byłaby dla tych mniej interesujących się życiem publicznym wyborców jedynym znanym obliczem władzy. Zresztą po jakimś czasie nikt poważny nie stanąłby z nim w wyborcze szranki, bo wynik tej konfrontacji byłby z góry przesądzony. Pozbawione realnego znaczenia partie stałyby się całkowicie fasadowe. Ci, którzy nie godziliby się na taki system, byliby coraz bardziej osamotnieni, gdyż całkowicie w swoim sprzeciwie nieskuteczni. De-

17 C. Trutkowski, A. Kurniewicz, op. cit. 
mokracja zamieniłaby się powoli w swoje przeciwieństwo: władzę jednostki i otaczajacej ją sieci nieformalnych powiązań.

Z czymś podobnym mamy do czynienia w tej chwili w bardzo wielu społecznościach lokalnych, w których władzę sprawują od lat te same osoby i związane z nimi grupy interesu. Demokracja wymaga wymiany ludzi władzy. Jak zauważył dziewiętnastowieczny brytyjski filozof polityki lord Acton: „Władza demoralizuje, a władza absolutna demoralizuje absolutnie”. Do tego dochodzi naturalny proces wypalenia zawodowego. Rządzący zbyt długo działają coraz bardziej rutynowo, mają coraz mniej nowych pomysłów. Coraz bardziej skupiają się na samym utrzymaniu władzy, a nie na jej używaniu dla publicznego dobra. Nawet najbardziej popularny z prezydentów polskich miast, prezydent Szczurek, nie ustrzegł się przed całkowicie irracjonalnym pomysłem rozbudowy lotniska w Gdyni.

Jest paradoksem, że mamy więcej demokracji na górze niż na dole. Złe prawo przekształciło lokalne władze w otoczonych dworami władców. Wpływowe lobby prezydentów, burmistrzów i wójtów nie chce zgodzić się na ograniczenie swojej władzy. Dopóki obowiąuje obecna ustawa, nie dziwmy się, że frekwencja w wyborach lokalnych jest tak niska, a chętnych do zmierzenia się z wiecznymi prezydentami niewielu. Wybory parlamentarne zmieniaja na ogół bardzo wiele, wybory samorządowe bardzo często nic.

\section{Konsekwencje zastąpienia dzielnic jednostkami pomocniczymi}

W 2010 r. z dwuletnim opóźnieniem od przedstawienia projektu reformy jednostek pomocniczych wprowadzono zmiany w ich funkcjonowaniu w Poznaniu. Niestety, projekt został poddany obróbce przez rozmaite grupy interesu. W rezultacie oryginalny projekt Fundacji Rozwoju Demokracji Lokalnej został niemal całkowicie zmieniony. Naruszał on bowiem zarówno interesy radnych miejskich, jak i działaczy osiedlowych. Z reformy zostało niewiele. Zamiast 16 dzielnic o zbliżonej liczbie ludności mamy 42 ,jednostki pomocnicze”, które bardzo różnią się między sobą nawet pod względem liczby ludności, zajmowanego obszaru i gęstości zaludnienia. Dla przykładu, na Piątkowie mieszka niemal 40 tys., a na Fabianowie-Kotowie - niespełna 2 tys. osób. Największa powierzchnię, przeszło 20 tys. $\mathrm{km}^{2}$, ma Antoninek-Zieliniec-Kobyle Pole, podczas gdy najmniejsze osiedle Sobieskiego i Marysieńki zajmuje jedynie obszar 0,8 km². Na „wielkomiejskim” Grunwaldzie Północ na 1 km² przypada 19 tys. osób, a w „wiejskim” Kiekrzu niespełna 170 osób. Już tylko te dane pokazuja, że rady tych osiedli mają odmienne problemy i różne możliwości działania.

Do tego sama biurokratyczna nazwa ,jednostka pomocnicza” odstręcza i wprowadza w błąd. Sugeruje, że to ,jednostki” pomagają administracji miejskiej, a przecież zasada pomocniczości, do której podobno to określenie nawiązuje, oznacza coś odwrotnego: to dół decyduje sam o sobie, a góra mu tylko $\mathrm{w}$ razie potrzeby pomaga. Do tego kompetencje rad zostały ograniczone. Nie powstały też tak oczekiwane przez mieszkańców „punkty obsługi”. Obywatele nadal muszą udawać się do centrum, aby załatwić sprawy urzędowe, nie wszystko przecież da się załatwić przez Internet i nie wszyscy potrafią się nim posługiwać. 
Osiedlowi działacze pracują społecznie i zmieniają swoje najbliższe otoczenie, jak potrafia. Nie dysponują jednak realną władzą. Maja słabe społeczne wsparcie, z reguły bowiem zostali wybrani przez zaledwie kilka procent mieszkańców. Co gorsza, przy tak niskiej frekwencji zorganizowana grupa może wygrać wybory i przeforsować swoje pomysły wbrew woli innych mieszkańców.

Wyodrębnione 42 ,jednostki pomocnicze" są nadal tylko obszarami urbanistyczno-geograficznymi, a nie całościami społeczno-kulturowymi i administracyjnymi. Nie mają swoich agor, miejsc spotkań mieszkańców. Nie stworzono nie tylko „punktów obsługi”, ale nie powstają też na nich nowe domy kultury. Poza szkołami brakuje publicznie dostępnych budynków komunalnych. Gdy brakuje agory, trudno o wyłanianie liderów. Działa więc mechanizm błędnego koła niemożności i obojętności.

Nie ma mowy o budowaniu lokalnej tożsamości bez odpowiedniego nazewnictwa i systemu identyfikacji wizualnej. Nazwy połączonych osiedli nie moga być mechanicznym połączeniem dotychczasowych nazw osiedli składowych. Warszawskie-Pomet-Maltańskie, Ostrów Tumski-Śródka-Zawady-Komandoria to nie sa nazwy własne. Inne nazwy z kolei - np. Zielony Dębiec - spełniaja ten warunek i sa atrakcyjne, ale nie funkcjonują w świadomości mieszkańców. $\mathrm{W}$ sferze wizualnej w przestrzeni publicznej panuje kompletny chaos. $\mathrm{Na}$ tablicach z nazwami ulic figurują często zupełnie inne lokalizacje niż te na urzędowej mapie, np. tradycyjne Marcelin czy Świt zamiast urzędowego Grunwald Północ. Bałagan panuje nawet w ramach tej samej „jednostki pomocniczej”, gdyż różne jej części na tablicach informacyjnych noszą różne nazwy.

Brak identyfikacji z osiedlami, brak agor, brak realnej władzy powoduja, że w wyborach na najniższym szczeblu uczestniczy znikomy odsetek mieszkańców. W wyborach w Poznaniu w 2011 i 2015 r. frekwencja wyniosła niespełna $8 \%$ i była bardzo zróżnicowana. W tym roku na niektórych poznańskich osiedlach wyniosła niemal $25 \%$, a na innych niespełna $3 \%$.

Bez podziału na takie dzielnice nie uda się zrealizować projektu prezydenta Poznania włączenia do miasta niektórych okolicznych gmin. Komorniki czy Suchy Las musiałaby zachować w ramach miasta pewną autonomię. Trudno sobie wyobrazić, aby nie chciały jej wtedy też inne dzielnice. Przed takim nowym podziałem miasta powinno się sporządzić społeczną mapę Poznania. Aby to było możliwe, nowe dzielnice musiałyby być jednocześnie tzw. obwodami statystycznymi, czyli obszarami, dla których agreguje się ważne dane o stanie lokalnych społeczności. Reforma musiałaby wziaćc pod uwagę różnice w poziomie życia i dostępie do rozmaitych usług pomiędzy poszczególnymi osiedlami. Ma bowiem służyć harmonijnemu i zrównoważonemu rozwojowi miasta, a nie pogłębianiu istniejących różnic.

\section{Frekwencja i głosy nieważne jako wskaźniki udziału w życiu publicznym lokalnej społeczności}

Frekwencja wyborcza jest jednym z lepszych wskaźników zainteresowania obywateli życiem publicznym społeczności, w której żyja. Generalnie frekwencja ta w Polsce jest ok. 20\% niższa niż średnia dla krajów Unii Europejskiej. W XXI w. powyżej 50\% obywateli RP uczestniczyło tylko w I turze wyborów pre- 
zydenckich w 2000 r., w referendum akcesyjnym w 2003, w II turze wyborów prezydenckich w 2005, w wyborach do parlamentu w 2007 oraz w obu turach wyborów prezydenckich w 2010. Najniższa była zawsze frekwencja wyborcza w wyborach do Parlamentu Europejskiego (poniżej 25\%). Frekwencja w wyborach samorządowych lokuje się pośrodku. Z reguły w I turze przekracza 40\%, w II zaś znajduje się poniżej tej wielkości. O ile generalnie frekwencja wyborcza jest większa w miastach, zwłaszcza największych, o tyle w przypadku wyborów lokalnych jest odwrotnie. Jak zauważają autorzy raportu:

Różnica w średniej frekwencji między gminami do 5 tys. mieszkańców, a osiagającymi najniższy wynik gminami od 100 do 500 tys. mieszkańców, wyniosła 17,7 pkt. proc. Zgodnie z tymi prawidłowościami, najwyższą średnią frekwencję wyborczą zanotowano w gminach wiejskich (55\%), najniższą zaś - generalnie w miastach na prawach powiatu (41\%). Dla gmin miejskich i miejsko-wiejskich wyniosła ona odpowiednio 48\% i 51\%. Jedynym wyjątkiem od tej reguły jest nieznaczny wzrost frekwencji w największych miastach (powyżej 500 tys. mieszkańców) ${ }^{18}$.

Co ciekawe, frekwencji nie podniosło wprowadzenie bezpośrednich wyborów wójtów, burmistrzów i prezydentów, które w dużych miastach teoretycznie mogło być czynnikiem zwiększajacym zainteresowanie wyborców, bo przypominającym wybory prezydenta RP. Głosuje się tu przecież na znane dobrze nazwiska. Tymczasem poza specyficznym przypadkiem Warszawy frekwencja w wyborach lokalnych największych polskich miast jest niższa od średniej krajowej. Trudno przy tym stwierdzić, czy wyższa frekwencja w stolicy wynika ze szczególnej polityczności tego miasta i medialności warszawskiej kampanii wyborczej, czy też raczej z unikatowego „dzielnicowego" ustroju tego miasta.

Ze względu na współwystępowanie wyborów do samorządowych wójtów, burmistrzów i prezydentów, rad gmin, rad powiatów i sejmików wojewódzkich istniejące między nimi znaczne różnice w odsetku głosów nieważnych można uznać za brak zaangażowania i w zasadzie można byłoby je odliczać od frekwencji. Jak piszą autorzy raportu:

W 2014 r. w wyborach na wójtów, burmistrzów i prezydentów miast stwierdzono 2,14\% głosów nieważnych, w wyborach do rad gmin i miast na prawach powiatu $-5,16 \%$, w wyborach do rad powiatu - 16,67\%. Najwyższy odsetek głosów nieważnych oddano w wyborach do sejmików wojewódzkich - 17,93\%. W porównaniu do 2010 r. można zaobserwować wzrost udziału głosów nieważnych w odniesieniu do wszystkich kategorii wyborów. Szczególnie znaczące różnice wystapiły w przypadku wyborów do rad powiatowych i sejmików wojewódzkich (wzrost o odpowiednio 8,49 pkt. proc. I 5,87 pkt. proc. $)^{19}$.

Jeżeli tak, to należałoby uznać, że frekwencja wyborcza w wyborach wójtów, burmistrzów i prezydentów wyniosła w 2014 r. ok. $45 \%$, w wyborach do rad gmin - ok. $42 \%$, w wyborach do rad powiatów - ok. $30 \%$, a w wyborach do sejmików wojewódzkich - poniżej 30\% uprawnionych do głosowania. Traktowanie głosów nieważnych w wyborach do sejmików jako głosów protestu wydaje się chyba nieuzasadnione. Ich powodem jest po prostu brak znajomości kandydatów, którzy w tych wyborach biora udział, a także brak wiedzy o kompetencjach tego szczebla władzy samorządowej.

18 C. Trutkowski, A. Kurniewicz, op. cit., s. 2.

19 Ibidem. 


\section{Władze lokalne i reforma samorządowa w badaniach opinii publicznej}

Polityka lokalna cieszy się mniejszym zainteresowaniem ośrodków badania opinii publicznej niż polityka krajowa i zagraniczna. Brakuje zatem pogłębionych badań tej tematyki. Z dostępnych danych wynika, że mimo niskiej frekwencji w wyborach samorządowych w porównaniu z wyborami parlamentarnymi i prezydenckimi obywatele uznaja, że mają większy wpływ na sprawy lokalne niż na sprawy krajowe. O ile u schyłku XX w. jedynie co czwarty badany przez CBOS uznawał, że ma jakiś wpływ na sprawy swojej gminy, o tyle obecnie przekonanie takie deklaruje co drugi badany. Interpretacja tego fenomenu jest trudna. Jednym z wielu możliwych wyjaśnień, jest teza Seymoura S. Lipseta dotycząca wyborców amerykańskich, że niska frekwencja świadczy o zadowoleniu mieszkańców, gdyż udają się do urn tylko wtedy, gdy chcą coś zmienić $^{20}$. Czy jednak w polskich warunkach mamy rzeczywiście do czynienia z podobnym zjawiskiem?

Tabela 1

Poczucie wpływu na sprawy swojego miasta, gminy [w \%]

\begin{tabular}{|l|r|r|r|r|r|r|r|r|r|r|r|}
\hline $\begin{array}{c}\text { Odpo- } \\
\text { wiedzi } \\
\text { respon- } \\
\text { dentów }\end{array}$ & \multicolumn{1992}{|c|}{} & $\mathbf{1 9 9 7}$ & $\mathbf{1 9 9 9}$ & $\mathbf{2 0 0 4}$ & $\mathbf{2 0 0 7}$ & $\mathbf{2 0 0 8}$ & $\mathbf{2 0 0 9}$ & $\mathbf{2 0 1 0}$ & $\mathbf{2 0 1 2}$ & $\mathbf{2 0 1 3}$ & $\mathbf{2 0 1 5}$ \\
\cline { 2 - 13 } & 16 & 26 & 25 & 34 & 42 & 39 & 42 & 52 & 50 & 42 & 49 \\
\hline Tak & 79 & 69 & 73 & 63 & 54 & 58 & 55 & 45 & 47 & 56 & 48 \\
\hline $\begin{array}{l}\text { Nie } \\
\text { Trudno } \\
\text { powiedzieć }\end{array}$ & 5 & 5 & 2 & 3 & 4 & 2 & 3 & 3 & 3 & 2 & 3 \\
\hline
\end{tabular}

Źródło: CBOS 2009, 2013, 2015.

Znacznie słabiej rosło poczucie wpływu obywateli na sprawy kraju. Pod koniec ubiegłego stulecia przekonanie takie żywił co dziesiąty, a obecnie co czwarty badany. Tu mamy jednak do czynienia z wyraźnym spadkiem poczucia sprawstwa w porównaniu z rekordowym rokiem 2010.

Tabela 2

Poczucie wpływu na sprawy kraju [w \%]

\begin{tabular}{|c|c|c|c|c|c|c|c|c|c|c|c|}
\hline \multirow{2}{*}{$\begin{array}{l}\text { Odpo- } \\
\text { wiedzi } \\
\text { respon- } \\
\text { dentów }\end{array}$} & \multicolumn{11}{|c|}{ Rok } \\
\hline & 1992 & 1997 & 1999 & 2004 & 2007 & 2008 & 2009 & 2010 & 2012 & 2013 & 2015 \\
\hline Tak & 7 & 19 & 11 & 15 & 24 & 30 & 25 & 36 & 30 & 19 & 24 \\
\hline $\mathrm{Nie}$ & 91 & 76 & 87 & 83 & 73 & 65 & 72 & 60 & 68 & 79 & 72 \\
\hline $\begin{array}{l}\text { Trudno } \\
\text { powiedzieć }\end{array}$ & 2 & 4 & 5 & 2 & 3 & 5 & 3 & 4 & 2 & 2 & 3 \\
\hline
\end{tabular}

Źródło: CBOS 2009, 2013, 2015.

${ }^{20}$ S. M. Lipset, Homo politicus. Społeczne podstawy polityki, PWN, Warszawa 1995. 
Badanie przeprowadzone dwadzieścia pięć lat po reformie samorządowej pokazuje, że mieszkańcy uznają swoją samorząd gminny za najważniejszy czynnik sprawczy spośród wszystkich szczebli władzy, z unijną włącznie.

Tabela 3

Ocena wpływu władzy na rozwój lokalny [w \%]

\begin{tabular}{|l|c|c|c|c|c|}
\hline \multirow{2}{*}{$\begin{array}{c}\text { Odpowie- } \\
\text { dzi respon- } \\
\text { dentów }\end{array}$} & \multicolumn{5}{|c|}{ W jakim stopniu, w Pana(i) ocenie, rozwój miejscowości, } \\
\cline { 2 - 6 } w której Pan(i) mieszka, zależy od: & $\begin{array}{c}\text { samorządu } \\
\text { gminnego }\end{array}$ & $\begin{array}{c}\text { samorządu } \\
\text { powiatowego }\end{array}$ & $\begin{array}{c}\text { samorządu } \\
\text { wojewódzkiego }\end{array}$ & $\begin{array}{c}\text { władz } \\
\text { centralnych }\end{array}$ & $\begin{array}{c}\text { Unii } \\
\text { Europejskiej }\end{array}$ \\
\hline $\begin{array}{l}\text { W bardzo } \\
\text { dużym } \\
\text { stopniu }\end{array}$ & 18 & 10 & 10 & 10,0 & 10 \\
\hline $\begin{array}{l}\text { W dość dużym } \\
\text { stopniu }\end{array}$ & 40 & 34 & 27 & 21,0 & 31 \\
\hline $\begin{array}{l}\text { W średnim } \\
\text { stopniu }\end{array}$ & 28 & 33 & 33 & 24,0 & 27 \\
\hline $\begin{array}{l}\text { W dość małym } \\
\text { stopniu }\end{array}$ & 6 & 9 & 9 & 17,5 & 10 \\
\hline $\begin{array}{l}\text { W bardzo } \\
\text { małym } \\
\text { stopniu }\end{array}$ & 3 & 4 & 4 & 15,0 & 12 \\
\hline $\begin{array}{l}\text { Trudno } \\
\text { powiedzieć }\end{array}$ & 5 & 10 & 19 & 12,0 & 10 \\
\hline
\end{tabular}

Źródło: CBOS 2015.

W świetle tych samych badań połowa badanych ocenia pozytywnie dokonania samorządów terytorialnych, ale niewiele mniej osób $(41,5 \%$, czyli odpowiedzi „ani pozytywny, ani negatywny” oraz „trudno powiedzieć”) nie potrafi takiej oceny dokonać.

\section{Tabela 4}

Ocena działalności samorządu terytorialnego dwadzieścia pięć lat po pierwszych wyborach [w \%]

\begin{tabular}{|l|c|}
\hline $\begin{array}{c}\text { W maju minie dwadzieścia pięć lat od pierwszych w powojennej Polsce wolnych wyborów } \\
\text { do rad, gmin i miast. Jaki jest, Pana(i) zdaniem, ogólny bilans wykonywania zadań } \\
\text { przez samorządy terytorialne? }\end{array}$ \\
\hline Zdecydowanie pozytywny & 5,0 \\
\hline Raczej pozytywny & 46,0 \\
\hline Ani pozytywny, ani negatywny & 30,5 \\
\hline Raczej negatywny & 5,0 \\
\hline Zdecydowanie negatywny & 2,0 \\
\hline Trudno powiedzieć & 11,0 \\
\hline
\end{tabular}

Źródło: CBOS 2015. 
Również około połowy badanych ocenia pozytywnie dokonane w 1999 i 2002 r. korekty reformy samorządowej z 1990 r.

Tabela 5

Ocena działalności władz samorządowych [w \%]

\begin{tabular}{|l|c|c|}
\hline \multirow{2}{*}{$\begin{array}{c}\text { Odpowiedzi } \\
\text { respondentów }\end{array}$} & $\begin{array}{c}\text { Czy, Pana(i) zdaniem, wladze samorządowe funkcjonują obecnie } \\
\text { lepiej czy też gorzej niż }\end{array}$ \\
\cline { 2 - 3 } & $\begin{array}{c}\text { związaną z wprowadzeniem } \\
\text { powiatów i zmniejszeniem } \\
\text { liczby województw? }\end{array}$ & $\begin{array}{c}\text { przed reformą z 2002 r., } \\
\text { związaną z wprowadzeniem } \\
\text { bezpośrednich wyborów na } \\
\text { stanowisko wójta, burmistrza } \\
\text { i prezydenta miasta? }\end{array}$ \\
\hline Zdecydowanie tak & 13,0 & 14 \\
\hline Raczej tak & 33,5 & 36 \\
\hline Raczej nie & 22,5 & 22 \\
\hline Zdecydowanie nie & 6,0 & 22 \\
\hline Trudno powiedzieć & 22,0 & 2 \\
\hline
\end{tabular}

Źródło: CBOS 2015.

Jednocześnie przeszło połowa badanych opowiada się za korektą korekty, czyli wprowadzeniem ograniczenia liczby kadencji wójta, burmistrza, prezydenta do dwóch.

Tabela 6

Stosunek do ograniczenia liczby kadencji urzędników samorządowych [w \%]

\begin{tabular}{|l|c|}
\hline \multicolumn{2}{|c|}{$\begin{array}{c}\text { Funkcję wójta gminy oraz burmistrza i prezydenta miasta można sprawować wiele } \\
\text { kadencji. Czy, Pana(i) zdaniem, powinno się wprowadzić prawo, które ograniczy } \\
\text { maksymalny czas sprawowania funkcji wójta/burmistrza/prezydenta miasta do } \\
\text { dwóch kadencji, czyli }\end{array}$} \\
\hline Zdecydowanie przerwy, czy też nie?
\end{tabular}

Źródło: CBOS 2015.

Jak widać z odpowiedzi przytoczonych w tabelach, badanie to miało zbyt skromny charakter, aby mogło być podstawą jakichś pogłębionych analiz stanu „samorządowej” świadomości” społeczeństwa polskiego w dwudziestą piąta rocznicę tej wielkiej ustrojowej reformy. 


\section{PODSUMOWANIE}

Artykuł ten nie jest wynikiem jakichś długoletnich, wieloaspektowych i systematycznych badań polskich samorządów, lecz raczej komentarzem socjologa-obserwatora polskiej transformacji. Socjologa interesującego się polskim życiem publicznym, mającego dostęp do rozmaitych socjologicznych danych zastanych, w latach 1992-2014 przeprowadzajacego od czasu do czasu niewielkie badania dotyczace relacji między władzami samorządowymi a mieszkańcami, zwłaszcza, choć nie tylko, w Poznaniu. Wreszcie, miałem w swoim życiu możność i zaszczyt rozmawiać z autorami, do których w tym artykule się odwołuję: w 1992 r., w trakcie pobytu na trzymiesięcznym stypendium w Institute of Local Governemnent Studies w Birmingham - z profesorem Johnem Stewartem, a w 2008 r., w trakcie prowadzenia badań nad reformą jednostek pomocniczych Poznania - z profesorem Jerzym Regulskim.

Obraz polskiego samorządu oglądany z tej perspektywy jest niejednoznaczny. Z jednej strony reformę można uznać za wielki sukces. Przede wszystkim organizacyjny. W ciagu paru tygodni 1990 r. udało się w każdej gminie odbudować (a raczej tak naprawdę zbudować od nowa) struktury samorządowe. Nie dokonano by tego, gdyby nie wcześniejszy ruch komitetów obywatelskich, które powstały przed wyborami 1989 r. jako ruch społeczny zorganizowany tym razem terytorialnie, a nie branżowo, jak w 1980 r. Drugim ogromnym sukcesem tej reformy jest to, że różnice cywilizacyjne między poszczególnymi regionami kraju są dziś znacznie mniej widoczne niż przed dwudziestu pięciu laty.

Podstawowym problem polskiego samorząu jest jego niewielki związek z praktyką i ideą społeczeństwa obywatelskiego. W publicznym dyskursie problematyka samorządności jest bardzo słabo obecna. Dominuje waskie, prawniczo-ekonomiczne traktowanie samorządu jako najniższego szczebla władzy zorientowanej raczej na mieszkańców-klientów niż na mieszkańców-obywateli. Choć w badaniach opinii publicznej mieszkańcy deklarują dość znaczne poczucie podmiotowości w kwestiach lokalnych, to dane o frekwencji wyborczej, zwłaszcza w dużych miastach i do samorządów szczebla wojewódzkiego raczej tego nie potwierdzają.

Poważnym problemem polskiego samorządu jest systemowa dysfunkcjonalność kanałów demokratycznej artykulacji interesów. Istniejące regulacje prawne po 2002 r. ograniczają rolę radnych, uprzywilejowując wójtów, burmistrzów i prezydentów. Jednocześnie ordynacja większościowa uniemożliwia (casus My-Poznaniacy w 2010 r.) lub utrudnia wprowadzenie do rad przedstawicieli rodzących się ruchów miejskich, uprzywilejowując partie polityczne. Wreszcie, likwidacja dzielnic w dużych miastach oddaliła, także w sensie przestrzennym, władze lokalne od obywateli. 


\section{DEFICIT OF CITIZENSHIP}

\section{Sum mary}

In this paper the self-government reform of 1990 and its subsequent corrections of 1999 and 2002 are analysed from a sociological perspective. The critical analysis focuses on two basic concepts of self-governance: (i) the concept based on decentralisation, democratisation and citizenfocused government as represented by the main author of the reform Jerzy Regulski, and (ii) the concept currently being developed at the British Institute of Local Government Studies authored by Michael Clark and John Stewart, proposing two types of relations between a local authority and local residents, and consequently two types of commune and municipality (gmina) management: one oriented on the inhabitant-client and one oriented on the citizen-client relationship. Based on the criticism of the reform articulated by Regulski fifteen years after its implementation, as well as on the current data and his own analysis, the author proposes that today, after another ten years, the same criticism pointing to the still insufficient treatment of local residents as the main focus, or object of self-government concern, has lost none of its topicality. The channels of the democratic articulation of the interests of different groups of commune and municipality (gmina) inhabitants do not function properly, which is particularly evident in big cities. 







\begin{tabular}{|c|c|c|c|c|c|c|c|c|c|c|c|}
\hline $\begin{array}{l}\text { 아 } \\
\text { م) }\end{array}$ & $\begin{array}{l}8 \\
8 \\
10\end{array}$ & $\underset{f}{\stackrel{m}{f}}$ & $\begin{array}{l}5 \\
\infty \\
10 \\
10\end{array}$ & 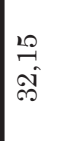 & 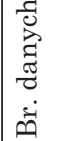 & $\begin{array}{l}10 \\
\infty \\
19 \\
7\end{array}$ & $\begin{array}{l}10 \\
\infty \\
10 \\
\infty\end{array}$ & 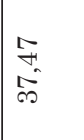 & $\begin{array}{l}1 \\
\infty \\
10 \\
\text { If }\end{array}$ & $\begin{array}{l}\stackrel{10}{1} \\
6 \\
0 \\
\text { N }\end{array}$ & م) \\
\hline \begin{tabular}{l}
00 \\
$\stackrel{2}{\circ}$ \\
\multirow{F}{*}{}
\end{tabular} & $\begin{array}{l}\overrightarrow{10} \\
\overrightarrow{50}\end{array}$ & $\begin{array}{l}\text { f } \\
\text { 今. }\end{array}$ & के & \begin{tabular}{|l} 
b \\
ले \\
की
\end{tabular} & 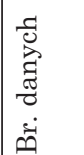 & 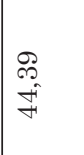 & 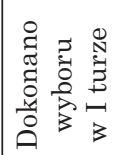 & $\begin{array}{l}0 \\
\stackrel{0}{0} \\
\infty \\
\infty\end{array}$ & 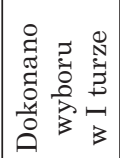 & $\begin{array}{l}\text { 동 } \\
\text { S) }\end{array}$ & $\begin{array}{l}\text { N } \\
\text { ล } \\
\text { ลે }\end{array}$ \\
\hline $\begin{array}{l}\text { ลे } \\
\text { ô } \\
\text { î }\end{array}$ & $\begin{array}{l}0 \\
0 \\
0 \\
+ \\
+\end{array}$ & $\begin{array}{l}\infty \\
0 \\
0 \\
0 \\
0\end{array}$ & $\begin{array}{l}0 \\
\text { Nิ } \\
\text { ôt } \\
0\end{array}$ & \begin{tabular}{|l}
$\infty$ \\
0 \\
0 \\
ஸे
\end{tabular} & 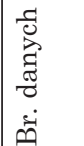 & $\begin{array}{l}\text { o } \\
\infty \\
\text { I } \\
\text { f }\end{array}$ & 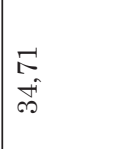 & \begin{tabular}{l}
$\mathscr{2}$ \\
\multirow{1}{*}{} \\
$\infty$ \\
$\infty$
\end{tabular} & $\begin{array}{l}\stackrel{10}{\mathrm{~N}} \\
\stackrel{\mathrm{N}}{\mathrm{N}}\end{array}$ & $\begin{array}{l}\infty \\
\infty \\
\infty \\
\curvearrowright\end{array}$ & $\begin{array}{l}\infty \\
\infty \\
0 \\
0\end{array}$ \\
\hline $\begin{array}{l}\text { Sू } \\
\text { की }\end{array}$ & $\begin{array}{l}\stackrel{2}{5} \\
\stackrel{+}{5}\end{array}$ & $\begin{array}{l}-1 \\
18 \\
0\end{array}$ & $\begin{array}{l}0 \\
2 \\
010 \\
10\end{array}$ & 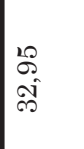 & 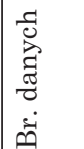 & $\begin{array}{l}H \\
0 \\
0 \\
O \\
+\end{array}$ & 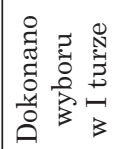 & 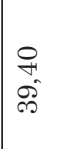 & 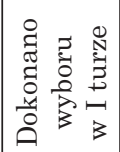 & $\begin{array}{l}0 \\
+ \\
\text { N } \\
\text { N }\end{array}$ & $\begin{array}{l}\vec{N} \\
\text { Lิ } \\
\text { a }\end{array}$ \\
\hline $\begin{array}{l}10 \\
10 \\
\infty 0^{\circ}\end{array}$ & $\begin{array}{l}8 \\
8 \\
f\end{array}$ & $\begin{array}{l}8 \\
81 \\
8\end{array}$ & $\begin{array}{l}\infty \\
\infty \\
0 \\
10 \\
10\end{array}$ & $\begin{array}{l}-\infty \\
\infty \\
20 \\
\text { N }\end{array}$ & 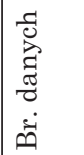 & $\begin{array}{l}- \\
0 \\
0 \\
0 \\
\infty\end{array}$ & $\begin{array}{l}0 \\
\stackrel{-}{-1}\end{array}$ & 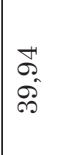 & $\begin{array}{l}\text { H. } \\
\text { on } \\
\text { Nิ }\end{array}$ & 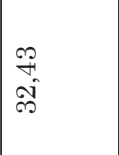 & 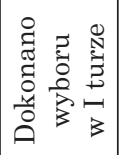 \\
\hline $\begin{array}{l}0 \\
10 \\
0 \\
10\end{array}$ & $\frac{0}{0}$ & $\begin{array}{l}0 \\
8 \\
0 \\
0\end{array}$ & 今ै & 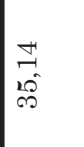 & 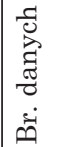 & $\begin{array}{l}\text { Oे } \\
\text { of } \\
\text { f }\end{array}$ & $\begin{array}{l}+ \\
\infty \\
\infty \\
\infty \\
\infty\end{array}$ & $\mid \begin{array}{l}\vec{\sim} \\
\stackrel{\alpha}{q}\end{array}$ & $\begin{array}{l}\tilde{\omega} \\
20 \\
10 \\
\infty\end{array}$ & $\begin{array}{l}10 \\
19 \\
9 \\
2\end{array}$ & $\begin{array}{l}2 \\
\stackrel{2}{0} \\
\stackrel{0}{1}\end{array}$ \\
\hline $\begin{array}{l}7 \\
7 \\
60 \\
60\end{array}$ & $\begin{array}{l}20 \\
0 \\
0 \\
10\end{array}$ & 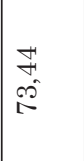 & $\begin{array}{l}10 \\
10 \\
5 \\
6\end{array}$ & 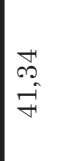 & 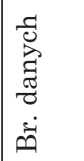 & $\begin{array}{l}0 \\
\mathscr{S} \\
\text { if } \\
i 0\end{array}$ & $\begin{array}{l}\Delta \\
0 \\
01 \\
10\end{array}$ & $\begin{array}{l}\alpha \\
\infty \\
\infty \\
\sigma\end{array}$ & 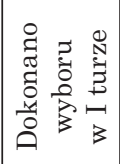 & $\begin{array}{l}\mathscr{S} \\
10 \\
\infty\end{array}$ & 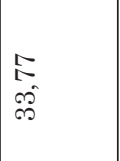 \\
\hline $\begin{array}{l}2 \\
\text { a } \\
0\end{array}$ & $\begin{array}{l}0 \\
\text { in } \\
\hat{\theta}\end{array}$ & $\begin{array}{l}\infty \\
\infty \\
i 0^{2}\end{array}$ & 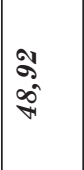 & \begin{tabular}{l}
\multirow{N}{*}{} \\
\multirow{\forall}{*}{}
\end{tabular} & 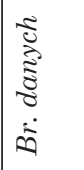 & $\begin{array}{l}2 \\
20 \\
3\end{array}$ & $\begin{array}{l}\dot{L}^{\circ} \\
\tilde{\sigma}^{\circ}\end{array}$ & $\begin{array}{l}\text { ⿵ั } \\
\text { Nิ }\end{array}$ & $\begin{array}{l}\widehat{\sigma} \\
20 \\
20\end{array}$ & 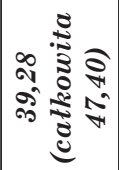 & 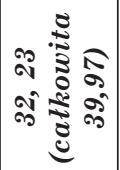 \\
\hline 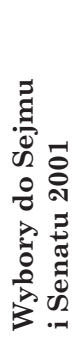 & 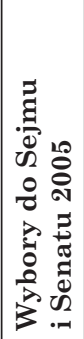 & 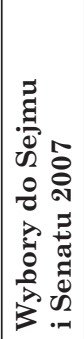 & 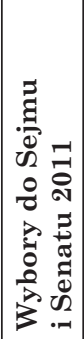 & 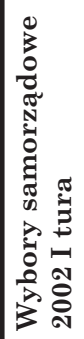 & 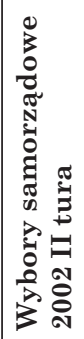 & 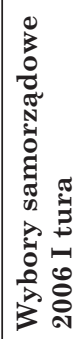 & 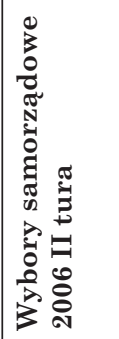 & 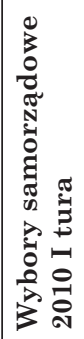 & 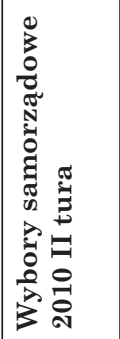 & 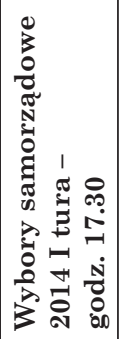 & 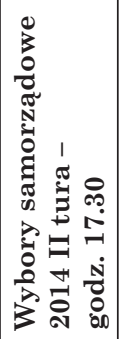 \\
\hline
\end{tabular}

